\title{
Persepsi Peserta Didik Terhadap Pembelajaran PJOK Secara Daring pada Masa Pandemi Covid-19
}

\author{
Yuhendar Evendi ${ }^{*}$, Wahjoedi ${ }^{2}$, I Ketut Semarayasa ${ }^{3}$ \\ 1,2,3 Jurusan Pendidikan Olahraga, Universitas Pendidikan Ganesha, Singaraja, Indonesia
}

\section{ART ICLE INF O}

\section{Article history:}

Received March 04, 2021

Revised March 06, 2021

Accepted September 07, 2021

Available online October 25, 2021

\section{Kata Kunci:}

Persepsi, Pembelajaran PJOK,

Pembelajaran Daring, Pandemi

Covid-19

\section{Keywords:}

Perception; PJOK learning; Learn to Be Courageous; Covid-19 pandemic

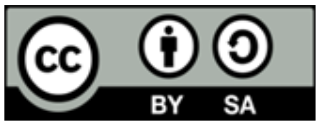

This is an open access article under the CC BY-SA license.

Copyright $(\subset 2021$ by Author. Published by Universitas Pendidikan Ganesha.

\begin{abstract}
A B S T R A K
Pandemic covid-19 telah membawa perubahan yang disignifikan terhadap proses pembelajaran. Dari yang belajar secara tatap muka menjadi belajar secara daring. Hal ini berpengaruh terhadap keinginan dan hasil belajar peserta didik. Penelitian ini bertujuan untuk mengetahui persepsi peserta didik terhadap pembelajaran PJOK secara daring pada masa pandemi covid-19. Penelitian ini tergolong dalam jenis penelitian deskriptif kualitatif. Rancangan dalam penelitian ini menggunakan teknik pengelola data skala likert dengan 5 kategori penilain. Metode yang digunakan dalam penelitian mengunakan metode survey. Teknik analisis data yang digunakan dalam penelitian ini menggunakan statistik deskriptif. Data penelitian didapatkan dari kuisioner yang disebarkan secara online melalui google form dengan jumlah responden 144 . Berdasarkan hasil analisis data dapat disimpulkan bahwa persepsi peserta didik terhadap pembelajaran PJOK secara daring pada masa pandemi covid-19, berada pada kategori cukup/sedang. Disarankan agar peserta didik lebih baik lagi dalam mengikuti pembelajaran daring yang diberikan oleh guru sehingga dapat meningkatkan hasil belajar yang ingin dicapai.
\end{abstract}

\begin{abstract}
A B S T RAK
The COVID-19 pandemic has brought significant changes to the learning process, from learning faceto-face to learning boldly. It affects the desire and learning outcomes of students. This study aims to bravely determine students' perceptions of learning PJOK during the covid-19 pandemic. This research belongs to the type of qualitative descriptive research. The design in this study uses a Likert scale data management technique with five categories of assessment. The method used in this research is the survey method. The data analysis technique used in this study used descriptive statistics. Research data was obtained from questionnaires distributed online via google form with 144 respondents. Based on the results of data analysis, it can be said that students' perceptions of learning PJOK bravely during the covid-19 pandemic were in the moderate/moderate category. It is recommended that students be better at following the bold learning given by the teacher to improve the learning outcomes to be achieved.
\end{abstract}

\section{PENDAHULUAN}

Pendidikan jasamani, Olahraga dan Kesehatan adalah pembelajaran yang efektif dan efin yang dapat membangun tanggung jawab, kesehatan jasmani, tanggung jawab serta kreatifitas melalui aktifitas fisik (Haris, 2018; Pambudi, Winarno, \& Dwiyogo, 2019; Wang, 2017). Pembelajaran PJOK bertujuan untuk membantu peserta didik dalam usaha meningkatkan derajat kesehatan kebugaran jasmani melalui keterampilan gerak dasar dalam mengembangkan aktivitas jasmani (Hanief \& Sugito, 2015; Wijaya \& Kanca, 2019). Jadi. Banyak hal yang perlu diperhatikan untuk kelancaran kegiatan belajar mengajar (KBM) di lapangan. Bukan hanya pemahaman materi semata, tetapi seorang guru PJOK harus mampu membuat suasana belajar yang menyenangkan, menarik, kondusif, efektif dan efesien (Buchari, 2018; Jaya, 2017). Pendidikan jasmani, Olahraga dan Kesehatan (PJOK) merupakan bagian integral dari pendidikan secara keseluruhan, yang bertujuan untuk membatu peserta didik dalam usaha meningkatkan derajat kesehatan kebugaran jasamani melalui keterampilan gerak dasar dalam berbagai aktivitas jasmani melalu aktivitas 
PJOK, yang mana setiap individu berhak mendapatkan perhatian yang sama sebagai anak didik, peran guru sangat penting dalam mencapai keberhasilan dari tujuan pembelajaran PJOK yang ingin dicapai (Hendri \& Azis, 2020; Raibowo \& Nopiyanto, 2020b; Rochman, Indahwati, \& Priambodo, 2020). Proses pembelajaran merupakan suatu peroses yang melibatkan interaksi antar peserta didik dengan guru maupun peserta didik dengan peserta didik, dimana interaksi tersebut peserta didik diharapkan mendapat pemahaman tentang apa yang diperoleh dalam situasi belajar mengajar. dalam proses pembelajaran guru harus dapat menciptakan suasan belajar yang menyenangkan, efektif dan efisien (Capella-Peris, Gil-Gómez, \& ChivaBartoll, 2020; Pramusinta, Setyosari, Widiati, \& Kuswandi, 2019; Raibowo \& Nopiyanto, 2020b). Prose pembelajaran yang menyenangkan akan membangkitkan motivasi serta minat siswa untuk belajar sehingga hasil belajarnya semakin baik (Friskawati \& Sobarna, 2019; Nataliya, 2016).

Namun yang terjadi saat ini proses pembelajaran kurang efektif. Hal ini merupakan dampak dari covid-19. Covid 19 adalah penyakit yang menyerang system pernafasan pada manusia, yang disebabkan oleh oleh Severe Acute Respiratory Syndrome Coronavirus-2 (SARS-CoV-2) (Purwanto et al., 2020; Susilo et al., 2020) (Putri \& Purwanto, 2020; Susilo et al., 2020). Virus ini telah menyebar ke seluruh dunia tidak terkecuali Indonesia. Sehingga untuk mencegah terus meluasnya penyebaran virus pemerintah mengeluarkan kebijakan diberbagai bidang. Pada bidang pendidikan pemerintah mengelurkan kebijakan untuk belajar dari rumah atau pembelajaran daring (Hadi, 2020; Pakpahan \& Fitriani, 2020). Pembelajaran daring merupakan pembelajaran yang menggunakan jaringan internet dengan memanfaatkan teknologi multimedia, video, kelas virtual, teks online animasi, pesan suara, email, telepon konferensi, dan video steraming online untuk memunculkan berbagai jenis interaksi pembelajaran (Fikri, Ananda, \& Faizah, 2021; Fitriyani \& Sari, 2020; Sadikin, A., \& Hamidah, 2020). Pembelajaran daring (online) menjadi tantangan serta pengalaman baru bagi pendidik serta peserta didik dalam melaksanakan kegiatan pembelajaran oleh karena itu antara guru dan peserta didik harus saling kerjasma untuk menciptakan suasana belajar yang kondusif. Namun dalam prakteknya banyak kendala yang dilamai oleh guru dan peserta didik. Permasalahan yang terjadi dan ditemui dalam pembelajaran PJOK adalah peserta didik masih sulit memahami materi yang diberikan karna tidak langsung peraktik di lapangan, terjadinya gangguan koneksi internet antara peserta didik dengan guru saat peroses pembelajaran, sehingga penyerapan materi yang disampaikan pada saat pelaksanaan pembelajaran terganggu. Gangguan sinyal menyebabkan fokus belajar peserta didik menajdi terganggu (Sukawati, 2021; Wijayanti \& Fauziah, 2020). Berdasarkan data awal di SMK Negeri 1 Mataram pada mata pembelajaran PJOK di kelas XI terhadap peserta didik masih mengalami permasalahan yang cukup serius baik itu pada saat pembelajaran dan hasil belajar peserta didik. Pembelajaran daring menyebabkan timbulnya berbagai persepsi terhadap proses pembelajaran.

Persepsi merupakan tanggapan atau pendapat seseorang terhadap sesuatu masalah yang dipertanyakan orang lain terhadap dirinya sehingga mendapakan jawaban atas masalah yang ditanyakan. Persepsi adalah proses yang menyangkut masuknya pesan atau informasi kedalam otak manusia. Melalui persepsi manusia terus-menerus mengadakan hubungan dengan lingkungannya. Hubungan ini dilewatkan dengan inderanya, yaitu indera penglihat, pendengar, peraba, perasa dan pencium (Slameto, 2015). Persepsi adalah proses yang digunakan individu mengelola dan menafsirkn kesan indera mereka dalam rangka memberikan makna kepada lingkungan mereka (Sobron, A.N., 2019; Sudiro, 2015). Meski demikian apa yang persepsikan seseorang dapat berbeda dari kenyataan objektif. Persepsi timbul karena danya faktor objek, pemahaman, penyerapan dan evaluasi. Persepsi bersifat individual. Persepsi juga muncul secara disadari ataupun tidak oleh seseorang sehingga dapat diartikan tanggapan seseorang terhadap sesuatu. Tanggapan tersebut muncul setelah sesorang menerima informasi ataupun stimulus yang telah dialami sebelumnya untuk dijadikan suatu referensi dalam bertindak. Persepsi dalam penelitian merupakan hal yang sangat penting untuk memecah masalah pembelajaran PJOK dimasa pandemic (Irawati \& Santaria, 2020; Nainggolan \& Manalu, 2021). Persepi yang baik terhadap pembelajaran PJOK diharapkan dapat memberi nilai lebih bagi siswa dalam rangka meningkatkan aktivitas berlajarnya disekolah.

Terdapat beberapa hasil penelitian terdahulu yang relevan dengan penelitian ini. Persepsi peserta didik terhadap pembelajsaran daring berada pada kategori baik, terlihat dari adanya minat dan motivasi siswa untuk belajar (Irawati \& Santaria, 2020; Sudirtha, 2016), penelitian oleh (Sari \& Nazirun, 2016) menunjukkan bahwa persepsi siswa terhadap proses pembelajaran pendidikan jasmani olahraga dan kesehatan adalah masuk kedalam kategori baik. Namun peserta didik jika diberikan memilih, mereka lebih senang belajar dengan tatap muka karena lebih mudah dimengerti serta prakteknya bisa dilakukan secara langusng (Hadi, 2020). Pembelajaran daring menimbulkan dampak positif namun juga tidak dapat terhindar dari dampak negatifnya. Sehingga perlu dilaksankan sebuah penelitian guna mengetahui bagaimana proses pembelajaran daring khusunya pada mata pelajaran. Penelitian ini bertujuan untuk mengetahui persepsi peserta didik terhadap pembelajaran PJOK secara daring pada masa pandemi covid19. 


\section{METODE}

Penelitian ini tergolong dalam jenis penelitian deskriptif kualitatif. Rancangan dalam penelitian ini menggunakan teknik pengelola data skala likert dengan 5 kategori penilain. Metode yang digunakan dalam penelitian mengunakan metode survey. Sampel dalam penelitian ini dengan jumlah 144 peserta didik sebagai reponden. Instrumen penelitian adalah alat bantu atau fasilitas yang digunakan oleh peneliti dalam mengumpulkan data agar pekerjaannya lebih mudah dan hasilnya lebih baik dalam arti lebih cermat, lengkap dan sistematis sehingga lebih mudah diolah (Arikunto, 2006). Adapun inturumen pengumpulan data dalam peneleitian ini yaitu: wawancara, kuesioner dan dokumentasi. Instrumen kuesioner dalam penelitian ini menggunakan penskoran dengan skala Likert. Skala Likert digunakan untuk mengukur sikap, pendapat dan persepsi seseorang atau sekelompok orang tentang fenomena social (Sugiyono, 2014). Dimana dalam pengunaan skala Likert ini responden akan memilih alternatif jawaban dari pertanyaan yang disediakan, masing-masing jawaban akan memiliki skor tertentu. Dalam penelitian ini penulis menggunakan 4 alternatif jawaban berserta dengan skornya dapat dilihat pada Tabel 1.

Tabel 1. Instrumen Skala Likert

\begin{tabular}{ccc}
\hline No & Skor & Keteranga \\
\hline 1 & Skor 5 & Sangat Sejutu \\
2 & Skor 4 & Setuju \\
3 & Skor 3 & Cukup Setuju \\
4 & Skor 2 & Tidak Sejutu \\
5 & Skor 1 & Sangat Tidak Setuju \\
\hline
\end{tabular}

Sebelum instrument kuesioner digunakan untuk pengumpulan data, maka instrumen kuesioner harus diuji tingkat validitas dan reliabilitas. Adapun teknik analisis yang digunakan peneliti adalah statistik deskriptif yang dituangkan dalam bentuk persentase, untuk mengatahui rentang skor dari persepsi peserta didik tentang pembelajaran PJOK secara daring pada masa pademi covid-19.

\section{HASIL DAN PEMBAHASAN}

Hasil

Hasil penelitian ini diambil dari, persepsi peserta didik SMK Negeri 1 Mataram pada kelas XI terhadap pemebelajaran PJOK secara daring pada masa pandemi covid-19. Dengan mengunkan indikator penyerapan/menyetujui, penegertian/pemahaman dan eveluasi/penilaian, sebagai acuan untuk mengeahui hasil penelitian, dengan cara uji validitas, uji realibilitas dan hasil rentang skor.

\section{Hasil Rentang Skor}

Hasil rentang skor didapatkan dari hasil analisis persepsi peserta didik SMK Negeri 1 Mataram pada kelas XI terhadap pembelajaran PJOK secara daring pada masa pandemi covid-19, yang menjadi sampel dalam penelitian ini dengan jumlah 144 peserta didik sebagai reponden. Berdasarkan indikator Tabel 2,3 dan 4 .

Tabel 2. Hasil Rentang Skor Penyerpan/Penerimaan

\begin{tabular}{|c|c|c|c|}
\hline Jumlah Pertanyaan & \multicolumn{2}{|c|}{ Jumlah Sampel } & Total Skor \\
\hline Pertanyaan 1-8 & \multicolumn{2}{|c|}{144} & 3835 \\
\hline Faktor & Skor & Rentang Skor & Kategori \\
\hline Penyerpan/penerimaan & $\begin{array}{l}3,33 \\
3,33\end{array}$ & $\begin{array}{c}2,66<x \leq 3,34 \\
2,66<x<3,34\end{array}$ & $\begin{array}{l}\text { Cukup baik } \\
\text { Cukun baik }\end{array}$ \\
\hline
\end{tabular}

Tabel 3. Hasil Rentang Skor Penegertian/Pemahaman

\begin{tabular}{|c|c|c|c|}
\hline Jumlah Pertanyaan & & ampel & Total Skor \\
\hline Pertanyaan 9-17 & \multicolumn{2}{|c|}{144} & 3909 \\
\hline Faktor & Skor & Rentang Skor & Kategori \\
\hline Pengertian/pemahaman & 3,02 & $2,66<x \leq 3,34$ & Cukup baik \\
\hline Total & 3,02 & $2,66<x \leq 3,34$ & Cukup baik \\
\hline
\end{tabular}


Tabel 4. Hasil Rentang Skor Evaluasi/Penilaian

\begin{tabular}{|c|c|c|c|}
\hline Jumlah Pertanyaan & \multicolumn{2}{|c|}{ Jumlah Sampel } & Total Skor \\
\hline Pertanyaan 18-20 & \multicolumn{2}{|c|}{144} & 1345 \\
\hline Faktor & Skor & Rentang Skor & Kategori \\
\hline Evaluasi/penilaian & 3,11 & $2,66<x \leq 3,34$ & Cukup baik \\
\hline
\end{tabular}

Dari hasil analisis data yang diproleh dari acuan hasil rentang skor sampel peserta didik, menunjukkan bahwa persepsi peserta didik terhadap pembelajaran PJOK secara daring pada masa pandemi covid-19, yaitu berada pada rentang skor cukup baik Melihat dari hasil rentang skor yang diproleh peneliti dapat mengambil kesimpulan bahwa, masih banyak perbaikan yang harus dibenahi dalam peroses pembelajaran daring, agar hasil nilai belajar peserta didik lebih baik lagi. Dalam penelitian ini mengacu pada indikator persepsi sebagai bahan patokan pembentukan kuisoner untuk menentukan hasil dari penelitian ini, adapun indikator yang digunakan dalam penelitian ini dibagi menjadi tiga bagian, yaitu penerimaan/penyerapan, pengertian/pemahaman dan evaluasi/penilaian.

\section{Pembahasan}

Hasil penelitian ini menyatakan pembelajaran persepsi peserta didik terhadap pembelajaran PJOK secara daring pada masa pandemi covid-19adalah cukup baik, ini berarti peserta didik telah mengikuti pembelajaran dengan baik dan sungguh-sungguh. Pendidikan jasamani dan kesehatan pada hakikatnya adalah proses pendidikan yang memanfaatkan aktivitas fisik dan kesehatan untuk menghasilkan perubahan holistik dalam kualitas individu, baik dalam hal fisik, mental, serta emosional (Aini \& Taufiq, 2018; Raibowo \& Nopiyanto, 2020a). Kesuksesan pembelajaran ditentukan oleh keterlibatan aktif guru dan peserta didik dalam lingkungan belajar (Gregorius, 2017; Saifulloh \& Darwis, 2020). Pada proses pembelajaran guru seharusnya mampu menciptakan suasana belajar yang efektif dengan menguasai serta harus pandai memanfaatkan media dalam menunjang pembelajaran yang akan dilakukan. Karena dengan pemilihan dan penggunaan media yang tepat guru akan lebih mudah menyampaikan materi kepada siswa (Fauzi \& Rosliyah, 2020; Prabawa \& Restami, 2020).

Indikator keberhasilan pembelajaran daring pada penelitain ini pertama penerimaan. Pembelajaran daring adalah hal yang baru bagi guru dan peserta didik. Pada pembelajaran daring dibutuhkan fasilitas yang memadai seperti, hp, laptop, serta jaringan internet yang mendukung. Sehingga guru dan peserta didik dipaksa untuk mengembangkan kemampuannya dalam menggunakan teknologi modern (Prabawa \& Restami, 2020). Sehingga untuk mencapai keberhasilan proses pembelajaran daring ini harus dimulai dengan tahap awal yaitu penerimaan system pembelajaran baru yaitu pembelajaran yang dilakukan secara online dengan memanfaatkan jaringan internet serta teknologi modern. Indikator kedua adalah pemahaman. Proses pembelajaran daring harus dipahami oleh guru maupun peserta didik. Jadi pada saat pelaksanaan pembelajaran guru dan peserta didik harus mampu bekerjasama guna mencapai keberhasilan pembelajaran. Guru sebagai komponen kebehasilan pembelajaran harus mampu menciptakan suasana belajar yang efektif dan kondusif sehingga siswa termotivasi untuk belajar dan konsentrasi saat guru menjelaskan materi (Aulia, 2018; Kurniati \& Liani, 2019). Evaluasi sangat penting untuk dilakukan untuk mengetahui tingkat pehamahan serta keberhasilan suatu pembelajaran. Untuk mengukur tingkat pemahaman peserta didik selama dilakukanya pembelajaran daring pada materi yang telah diberikan oleh guru baik dari aspek sikap, pengetahuan dan ketrampilan. guru dapat melakukan penilaian aspek sikap berupa kehadiran, disiplin, kerjasama, partisipasi dan tanggungjawab (Emilia, Ismanto, \& Luhsasi, 2021). Hasil dari evaluasi ini dapat dijadikan oleh guru sebagai acuan saat melaksanakan pembelajaran selanjutnya. Sehingga tujuan dari pembelajaran dapat dicapai. Kunci utama dari keberhasilan belajar siswa adalah kebiasaan belajar baik. Kebiasaan belajar yang baik akan membuat siswa memperoleh prestasi belajar yang tinggi (Magrifah, 2015; Rusmiyati, 2017). Suasana belajar yang baik merupakan suasana yang tepat dalam memahami apa yang sedang dipelajari oleh siswa tersebut, dengan begitu penguasaan terhadap suatu materi pelajaran akan semakin meningkat. Evaluasi pembelajran juga diperlukan untuk mengetahui persepsi atau pendapat peserta didik selama mengikuti proses pembelajaran. Pembelajaran yang dilakukan secara daring untuk mencegah penyebaran virus corona juga membawa dampak positif yaitu peserta didik menambah pengetahun tentang teknologi, bisa belajar dengan leluasa di rumah, serta dengan belajar di rumah orang tua akan bisa memperhatikan perkebangan anaknya secara lebih dekat (Oktafia Ika., 2020). Sehingga dalam proses pembelajaran daring dibutuhkan kerjasama antara guru, orang tua, peserta didik bahkan lingkungan sekitarnya. Pembelajaran daring membawa angin segar dalam proses pembelajaran sehingga banyak peserta didik yang lebih suka belajar online daripada belajar secara tatap muka (Adila \& Harisah, 2020). 
Berdasarkan beberapa penelitian tersebut dapat dikatakan bahwa pembelajaring daring yang dilakukan pada msa pandemic memperoleh hasil yang baik. Dalam pelaksanaan pembelajaran daring guru harus mengambangkan keterampilan mengajar seperti keterampilan mengadakan variasi, keterampilan bertanya, dan keterampilan memberi penguatan dalam pembelajaran daring agar saat prose pembelajaran siswa fokus sehingga dapat belajar dengan baik. Implikasi dari hasil temuan-temuan pada penelitian ini yaitu temuan ini dapat digunakan sebagai tambahan informasi mengenai pelaksanaan pembelajar daring pada mata pelajaran PJOK saat pandemi covid-19.

\section{SIMPULAN DAN SARAN}

Berdasarkan hasil penelitian dapat disimpulkan bahwa persepsi peserta didik terhadap pembelajaran PJOK secara daring pada masa pandemi covid-19 cukup baik. Sehingga pada proses pembelajaran guru harus kreatif dalam memilih metode saat penyampaian materi. Juga dengan lebih banyak menggunakan media sehingga peserta didik senang dan termotivasi untuk belajar sehingga dapat berpenaruh terhadap hasil belajarnya. Dari peserta didik harus pintar untuk memanfaatkan waktu walaupun belajar dari rumah hasus tetap semangat dan serius dalam mengikuti pembelajaran agar tidak tertinggal dengan teman-teman yanglain. Pembelajaran daring diharapkan mampu membatu baik guru maupun siswa agar lebih mudah dalam berkomunikasi dan belajar untuk menggunakan aplikasi-aplikasi yang tersedia guna menambah sumber belajar.

\section{DAFTAR RUJUKAN}

Adila, K., \& Harisah, Y. (2020). Persepsi Siswa Kelas X MIPA SMA Negeri 1 Bojong Terhadap Pembelajaran Online pada Pelajaran Mate matika. Seminar Nasional Pendidikan Matematika, 1(1), 401-406. Retrieved from https://proceeding.unikal.ac.id/index.php/sandika/article/download/433/359/.

Aini, H. N., \& Taufiq, H. (2018). Pengaruh Model Pembelajaran Kooperatif Tipe Stad Terhadap Hasil Belajar Servis Bawah Bolavoli. Jurnal Pendidikan Olahraga Kesehatan, 6(2), 519-525.

Arikunto. (2006). Prosedur Penelitian Suatu Pendekatan Praktik. jakarta: PT Rineka Cipta.

Aulia, V. (2018). Implementasi Keterampilan Mengadakan Variasi pada Praktik Pengalaman Lapangan Mahasiswa Program Studi Pendidikan Bahasa Inggris STKIP PGRI Banjarmasin. Jurnal Mitra Manajemen, 2(5), 5-5-521. https://doi.org/https://doi.org/10.52160/ejmm.v2i5.155.

Buchari, A. (2018). Peran Guru Dalam Pengelolaan Pembelajaran. Jurnal Ilmiah Iqra', $12(2), 106$. https://doi.org/10.30984/jii.v12i2.897.

Capella-Peris, C., Gil-Gómez, J., \& Chiva-Bartoll, Ò. (2020). Innovative analysis of service-learning effects in physical education: A mixed-methods approach. Journal of Teaching in Physical Education, 39(1). https://doi.org/10.1123/jtpe.2019-0030.

Emilia, J., Ismanto, B., \& Luhsasi, D. I. (2021). Evaluasi Implementasi Pembelajaran Daring pada Pembelajaran Akuntansi Perusahaan Dagang di Masa Pandemi Covid-19. Jurnal Kependidikan: Jurnal Hasil Penelitian Dan Kajian Kepustakaan, 7(3), 663-671. https://doi.org/10.33394/jk.v7i3.3849.

Fauzi, H. N., \& Rosliyah, Y. (2020). Persepsi Pembelajar terhadap Media Kamus Tematik Berbasis Web bagi Pembelajar Kosakata bahasa Jepang Tingkat Dasar. CHI'E: Jurnal Pendidikan Bahasa Jepang, 8(1), 25-32. https://doi.org/10.15294/chie.v8i1.35752.

Fikri, M., Ananda, M. Z., \& Faizah, N. (2021). Kendala Dalam Pembelajaran Jarak Jauh di Masa Pandemi Covid19 : Sebuah Kajian Kritis. Jurnal Education and Development Institut Pendidikan Tapanuli Selatan, 9(1), 145-148. https://doi.org/10.37081/ed.v9i1.2290.

Fitriyani, \& Sari. (2020). Motivasi Belajar Mahasiswa Pada Pembelajaran Daring Selama Pandemik Covid19. Jurnal Kependidikan: Jurnal Hasil Penelitian Dan Kajian Kepustakaan Di Bidang Pendidikan, $\begin{array}{llll}\text { Pengajaran, Dembelajaran, } & \text { 6(2), }\end{array}$ https://doi.org/https://doi.org/10.33394/jk.v6i2.2654.

Friskawati, G. F., \& Sobarna, A. (2019). Faktor Internal Pencapaian Hasil Belajar Pendidikan Jasmani pada Siswa SMK. Jurnal Penelitian Pendidikan, 18(3). https://doi.org/10.17509/jpp.v18i3.15004.

Gregorius, R. M. (2017). Performance of Underprepared Students in Traditional Versus Animation -Based Flipped -Classroom Settings. Chemistry Education Research and Practice, 18(4), 841-848. https://doi.org/10.1039/c7rp00130d.

Hadi, L. (2020). Persepsi Mahasiswa Terhadap Pembelajaran Daring Di Masa Pandemik Covid-19 Student Perceptions of Online Learning During Covid-19 Pandemic. Jurnal Zarah, 8(2), 56-61. https://doi.org/10.31629/zarah.v8i2.2464.

Hanief, Y. N., \& Sugito, S. (2015). Membentuk Gerak Dasar Pada Siswa Sekolah Dasar Melalui Permainan 
Tradisional. Jurnal SPORTIF: Jurnal Penelitian Pembelajaran. https://doi.org/10.29407/js_unpgri.v1i1.575.

Haris, I. N. (2018). Model pembelajaran peer teaching dalam pembelajaran pendidikan jasmani. Journal of Chemical Information and Modeling, 4(9), 2.

Hendri, G., \& Azis, I. (2020). Motivasi siswa dalam proses pembelajaran pendidikan jasmani olahraga kesehatan. Jurnal Patriot, 2(1), 171-181.

Irawati, R., \& Santaria, R. (2020). Persepsi Siswa SMAN 1 Palopo Terhadap Pelaksanaan Pembelajaran Daring Mata Pelajaran Kimia. Jurnal Studi Guru Dan Pembelajaran, 3(2), 264-270. https://doi.org/10.30605/jsgp.3.2.2020.286.

Jaya, H. N. (2017). Keterampilan Dasar Guru untuk Menciptakan Suasana Belajar yang Menyenangkan. Pendidikan Dan Ilmu Pengetahuan, 17(1), 23-35. https://doi.org/10.30651/didaktis.v17i1.1555.

Kurniati, T., \& Liani, U. (2019). Peningkatan Keterampilan Mengadakan Variasi pada Mahasiswa Program Studi Pendidikan Kimia. Jurnal Ilmiah Ar-Razi, 7(1), 33-38. https://doi.org/http://dx.doi.org/10.29406/ar-r.v7i1.1379.

Magrifah. (2015). Pengaruh Konsep Diri dan Kebiasaan Belajar Terhadap Hasil Belajar Matematika Siswa Kelas VIII SMP Negeri 6 Bontomantene. Mapan: Jurnal Matematika Dan Pembelajaran, 3(1). https://doi.org/https://doi.org/10.24252/mapan.2015v3n1a9.

Nainggolan, A. P., \& Manalu, R. B. B. (2021). Pengaruh Penggunaan Google Classroom Terhadap Efektifitas Pembelajaran. Journal Coaching Education Sports, 2(1), 17-30. https://doi.org/10.31599/jces.v2i1.515.

Nataliya, P. (2016). Efektivitas Penggunaan Media Pembelajaran Permainan Tradisional Congklak Untuk Meningkatkan Kemampuan Berhitung Pada Siswa Sekolah Dasar. Ilmiah Psikologi Terapan, 03(02), 343-358. https://doi.org/https://doi.org/10.22219/jipt.v3i2.3536.

Oktafia Ika. (2020). Pembelajaran Daring Sebagai Upaya Study From Home (SFH) Selama Pandemi Covid 19. https://doi.org/. Jurnal Pendidikan Administrasi Perkantoran (JPAP), 3(8), 496-503. https://doi.org/10.1093/fampra/cmy005.

Pakpahan, R., \& Fitriani, Y. (2020). Analisa Pemafaatan Teknologi Informasi Dalam Pemeblajaran Jarak Jauh Di Tengah Pandemi Virus Corona Covid-19. JISAMAR (Journal of Information System, Applied, Management, Accounting and Researh), 4(2), 30-36.

Pambudi, M. I., Winarno, M., \& Dwiyogo, W. D. (2019). Perencanaan dan Pelaksanaan Pembelajaran Pendidikan Jasmani Olahraga Kesehatan. Jurnal Pendidikan Olahraga, Universitas Negeri Malang, 4(1), 110-116.

Prabawa, D. G. A. P., \& Restami, M. P. (2020). Pengembangan Multimedia Tematik Berpendekatan Saintifik untuk Siswa Sekolah Dasar. Mimbar PGSD Undikhsa, 8(3), 479-491.

Pramusinta, Y., Setyosari, P., Widiati, U., \& Kuswandi, D. (2019). Exploring metacognitive and critical thinking skills of pre-service elementary school teachers through discovery learning method by integrating various cognitive styles. Journal for the Education of Gifted Young Scientists, 7(4). https://doi.org/10.17478/jegys.614028.

Purwanto, A., Pramono, R., Asbari, M., Santoso, P. B., Wijayanti, L. M., Choi, C. H., \& Putri, R. S. (2020). Studi Eksploratif Dampak Pandemi COVID-19 Terhadap Proses Pembelajaran Online di Sekolah Dasar. EduPsyCouns: Journal of Education, Psychology and Counseling, 2(1), 1-12.

Putri, R. S., \& Purwanto, D. (2020). (2020). Impact of the COVID-19 pandemic on online home learning: An explorative study of primary schools in Indonesia. International ,. Journal of Advanced Science and Technology, 29(5), 4809-4818.

Raibowo, S., \& Nopiyanto, Y. E. (2020a). Evaluasi Pembelajaran Pendidikan Jasmani Olahraga \& Kesehatan pada SMP Negeri Se-Kabupaten Mukomuko melalui Pendekatan Model Context, Input, Process \& Product ( CIPP ). Jurnal Pendidikan Kesehatan Rekreasi, 6(2), 146-165. https://doi.org/10.5281/zenodo.3881891.

Raibowo, S., \& Nopiyanto, Y. E. (2020b). Proses Belajar Mengajar Pjok Di Masa Pandemi Covid-19. STAND : Journal Sports Teaching and Development, 1(2), 112-119. https://doi.org/10.36456/jstand.v1i2.2774.

Rochman, B., Indahwati, N., \& Priambodo, A. (2020). Identifikasi Keterlaksanaan Pembelajaran PJOK Tingkat SMP Di Masa Pandemi Covid 19 Se-Kabupaten Sidoarjo. Jurnal Ilmiah Mandala Education, 6(1), 257-265. https://doi.org/10.36312/jime.v6i1.1343.

Rusmiyati, F. (2017). Pengaruh Kemandirian Dan Kebiasaan Belajar Terhadap Prestasi Belajar Metematika Siswa Kelas X Sma Negeri 1 Rongkop. UNION: Jurnal Ilmiah Pendidikan Matematika, 5(1), 77. https://doi.org/10.30738/.v5i1.931.

Sadikin, A., \& Hamidah, A. (2020). Pembelajaran Daring di Tengah Wabah Covid-19. Biodik, 6(2), 109-119. https://doi.org/10.22437/bio.v6i2.9759. 
Saifulloh, A. M., \& Darwis, M. (2020). Manajemen Pembelajaran dalam Meningkatkan Efektivitas Proses Belajar Mengajar di Masa Pandemi Covid-19. Bidayatuna: Jurnal Pendidikan Guru Mandrasah Ibtidaiyah, 3(2), 285. https://doi.org/10.36835/bidayatuna.v3i2.638.

Sari, M., \& Nazirun, N. (2016). Persepsi Siswa Kelas Viii Terhadap Proses Pembelajaran Pendidikan Jasmani Olahraga Dan Kesehatan Di Smp Negeri 5 Pekanbaru. Journal of Chemical Information and Modeling, 1(269-277), 269-277.

Slameto. (2015). Metodelogi Penelitian \& Inovasi Pendidikan. Salatiga: Cipta.

Sobron, A.N., D. (2019). Persepsi Siswa dalam Studi Pengaruh Daring Learning Terhadap Minat Belajar IPA. Retrieved from https://ejournal.insuriponorogo.ac.id/index.php/scaffolding/article/view/117.

Sudiro. (2015). Pengaruh Sarana, Proses Pembelajaran, Dan Persepsi Kinerja Dosen Terhadap Kepuasan Mahasiswa Pada Politeknik Indonusa surakarta. Jurnal Sainstech Politeknik Indonusa Surakarta, $1(4), 10-14$.

Sudirtha, I. G. (2016). Pengaruh ModelPembelajaran dan Bentuk Asesmen Formatif Terhadap Hasil Belajar Micro Teaching dengan Mengontrol Persepsi Tentang Profesi Keguruan. Studi Eksperimen Pada Mahasiswa FTK Undiksha Program Pascasarjana Uni.

Sugiyono. (2014). Metode Penelitian Kualitatif dan R\&D. Alfabeta.

Sukawati, S. (2021). Pemanfaatan zoom meeting dan google classroom dalam mata kuliah inovasi. Jurnal Semantik, 10(1), 45-54. https: //doi.org/10.22460/semantik.v10i1.p45-54.

Susilo, A., Rumende, C. M., Pitoyo, C. W., Santoso, W. D., Yulianti, M., Herikurniawan, H., ... Yunihastuti, E. (2020). Coronavirus Disease 2019: Tinjauan Literatur Terkini. Jurnal Penyakit Dalam Indonesia, 7(1), 45. https: //doi.org/10.7454/jpdi.v7i1.415.

Wang, R. (2017). Research on the reform of physical education and training mode in universities based on information technology. Journal of Mathematics Science and Technology Education, 55(14), 266273.

Wijaya, M. A., \& Kanca, N. (2019). Media Pembelajaran Aktivitas Pengembangan PJOK untuk Pendidikan Dasar dan Menengah. JOSSAE: Journal of Sport Science and Education, 4(1), 1. https://doi.org/10.26740/jossae.v4n1.p1-6.

Wijayanti, R. M., \& Fauziah, P. Y. (2020). Perspektif dan Peran Orangtua dalam Program PJJ Masa Pandemi Covid-19 di PAUD. Jurnal Obsesi: Jurnal Pendidikan Anak Usia Dini, 5(2), 1304-1312. https://doi.org/10.31004/obsesi.v5i2.768. 